\title{
Educating girls in Congo: An unsolved pedagogical paradox since colonial times?
}

Policy Futures in Education $0(0) 1-17$

(C) The Author(s) 2018 Reprints and permissions: sagepub.co.uk/journalsPermissions.nav DOI: 10.1 | 77//4782I03/8767450 journals.sagepub.com/home/pfe

$\Theta$ SAGE

\section{Marc Depaepe}

Centre for the History of Intercultural Relations, KU Leuven,

Campus Kulak, Belgium

\section{Annette Lembagusala Kikumbi}

Centre for the History of Intercultural Relations, KU Leuven, Campus

Kulak, Belgium

\begin{abstract}
Generally speaking, colonial education in Congo did not engender a very great widening of consciousness among the local population. Mostly, it resulted in inevitable submission through discipline and order. This was particularly the case for girls, for which fewer initiatives were taken than for boys. Moreover, gender stereotypes from the 'mother' country clearly dominated the evolution of female education in Congo. At best girls were trained for care-taking professions. After independence, some Congolese leaders, like Mulele (the first Minister of Education of the Democratic Republic of Congo) and Mobutu (who called himself 'the founding president of Zaire') wanted to break the colonial tradition by putting education in a more authentic African context. However, both educational models - the one of Mulele as well as the one of his adversary Mobutu - were in the end not very successful. The least we can say, at the basis of some oral history, is that the pedagogical paradox between the rhetoric of emancipation and the existing everyday educational realities in Africa is far from being solved.
\end{abstract}

\section{Keywords}

Colonial and post-colonial education, Congo, educational historiography, girls' education 


\section{Introduction and subject of critical analysis}

With regard to the history of education in Congo, we have repeatedly argued that one ought not speak so much of opportunities for emancipation during the period of colonisation, but rather of an entrenched and lasting paternalistic relationship. Until around 1960 - the year in which Congo gained its independence - the mental space allotted to the education of the native population was of meagre significance, both quantitatively and qualitatively speaking. If this was the case for colonial education in general, it was even more pronounced when it came to the education of girls. Not only were there fewer initiatives undertaken for girls than for boys, but in addition, they were limited to the curriculum of a parallel learning path, which in conforming to perspectives on gender prevalent at the time, restricted access solely to specific care-oriented professions, such as nun, schoolteacher, monitrice (teaching assistant), nurse/nursing assistant and midwife/midwife's assistant. This emphasis on the 'assisting' role of these aides betrayed the colonial mind-set.

Naturally, the Belgian officials - those making policy as well as those responsible for its implementation, particularly Catholic missionaries - drew their inspiration from the 'motherland' where, at that time, in so far as there was an identical, stereotypical gendered mentality with regard to the societal role of men and women, the same pedagogical approaches were present. It was from the fields of teaching and education that the vast majority of Belgian missionaries, where Flanders was certainly no exception, stemmed, all of them equally focussed on obedience, obeisance to authority, finding one's place in the social order and, as such and above all, conforming to socially desirable values and norms especially those associated with the so-called cult of domesticity.

However, what has stood out for us, from the inception of our study, is that the pedagogical regime encompassing the discipline and submission of the African population still played a considerably weightier role than in Belgium. The prevailing dictum of the civilising mission as a legitimisation of the industrial and economic exploitation of Congo was predicated on the superiority of Western, or in this case Christian, culture. This had to be established at an accelerated pace and within a pagan - that is, an alien and inferior context, one that was also often construed as being hostile. With this 'grand' endeavour in mind, those involved were also far less inhibited when it came to allowing prevailing stereotypes to surface than they would have been in Europe. As we have stated elsewhere (Depaepe, 2017), teaching and education in the colony were, so to speak, like 'high-pressure cooking', to the extent that the characteristics, to include flaws and systemic failures of the Western model of education, became much more easily visible than they would have been in a complex form of society.

To be clear, this finding does not directly imply a condemnation of the pedagogical past, let alone of the players of the time - something that is often wrongfully attributed to us in explanations intended for a broad audience. Being averse to any type of philosophical presentism, we are merely seeking to understand and explain, through historical research of sources and literature, how the processes and structures of colonial and post-colonial educational mindsets and realities intertwine and how they have continued to work throughout successive periods of political upheaval despite the specific historical circumstances.

In the present essay this is cast from a perspective on policy and goals related to girls' education, concerning which it may be said at the very least that the pedagogical paradoxes birthed through paternalism's pursuit of autonomy most certainly also persisted following independence, in the same way, for that matter, that the corresponding gaps between 
educational realities and rhetoric persisted. Up until now in educational historiography, little attention has been paid to the history of Congolese girls' education (Kita, 2004) and certainly none to the interdependence between colonial and post-colonial times. The same may be said, mutatis mutandis, with regard to the literature on gender and missionary work (Dujardin, 2003). Whilst a few noteworthy publications on this matter have recently been released in France, these dual aspects, certainly as far as the Belgian context is concerned, have not been sufficiently linked to each other to date. Partly on the basis of various monographs produced at the Research Centre for Educational History of KU Leuven, and in which the work of the Sisters of Charity (Ghent) (Ghijssels, 1995) and the Sisters of the Annunciation (Heverlee) (Christens, 2003) has a central role, we propose a modest summary below. This will be followed by a focus on the developments of the colonial educational environment, the Maoist-inspired camps of Mulele and the Africanisation attempts by Mobutu.

\section{The effects of colonisation}

Traditionally, Belgian colonisation is said to start with the signing of the Berlin Act in 1885, in which the European leaders of the time formally recognised the Free Congo State, with Leopold II as its head of state, despite the king already having begun the exploration and exploitation of Central Africa in 1878. It was only in 1908 that Congo, faced with international pressure, would become an actual Belgian colony. That period lasted until 1960, when the country became independent, again with the endorsement of the international community.

In the time that has passed since then, and in part due to our study (Depaepe and Van Rompaey, 1995), our understanding of the overall development of teaching and education during the colonial era has expanded considerably. Conversely, there is much less available about the Leopoldian period; that being said, A. M. Delathuy (1992-1994) in his critical analyses of the relationship between church and state at the time, has provided very clear indications about the then harsh, if not horrific, pedagogical regime. According to him, girls in the 'school colonies' intended for them - as the institutions for children who were wards of the state (often orphaned or carried off as a result of military raids and punitive expeditions) were called - received identical punishment to what boys did (for whom separate school colonies existed under the supervision of the priests). For example, he writes that the Sisters of Charity, who in 1892 started the first school colony for girls in Moanda, also employed the chicotte (whip), put their pupils in chains or put them into a sort of straitjacket at their school in Kikanda. Reportedly, little or none of this can be found in the sisters' archive itself, but in any case, the study of that archive sufficiently demonstrates that one of the main concerns of the sisters was being able to arrange marriages, through their school colonies, with the boys from the priests' mission. In this way they hoped to establish stable families for future soldiers, catechists, labourers and administrative assistants recruited from the local population. At the same time, Christian culture was to be adopted by the employees of the colonial system, who served as an important example to the remaining indigenous population. Incidentally, such objectives did not differ significantly from what was customary at the Protestant mission schools, although the level of education was usually slightly higher there (Yates, 1967).

What is striking now is that many of the practices and prejudices of the Leopoldian era with regard to Congolese girls' education continued to have a very strong effect in the 
decades that followed. Certainly, up until the Second World War, the emphasis in Congolese girls' education was on moral instruction and the maintenance of discipline, with manual labour serving to keep up the mission as its focal point. With a view to involvement in social life, as future wives and mothers, the importance of a practical training was stressed, as was the formation of character and will, although the latter was regarded as being of more concern for boys than for girls. In this respect, and in keeping with the Western division of labour between men and women, a programme was proposed in which the basic rules of hygiene, child care (including instructions on breastfeeding) and housekeeping were taught. Washing, sweeping, cooking, sewing, knitting and sometimes even women's handicrafts (such as the making of raffia baskets and other 'native'-like souvenirs), embroidery and manufacture of clothing (for the biracial population there might even have been additional tasks) were invariably part of the repertoire of skills to be learned.

Specifically, in the colonial era, so-called 'special' schools for girls were founded in which the ideal template of the pious, submissive housewife, raised in the Christian faith, was to be spread explicitly. In contrast to Protestants, Catholics did not advocate coeducation, instead aiming for as much gender-specific education as possible. In 1929, the Belgian curriculum for Congo provided, after the first level of primary education (two or at most three years of study in the country, and three in the city), for a three-year agricultural housekeeping school and a three-year normal division for girls. In 1938, this format was adjusted, with the understanding that the second level of primary education (four years of study, including the first level) now had to be completed before one could attend these special schools. Moreover, within the same framework of special schools, a separate, three-year primary teacher training college was now also provided for girls (with a possible preparatory year), whilst the teacher training colleges for boys effectively obtained a four-year curriculum in the 1938 reform, which again highlights the second-class position of girls' education (see, e.g., Gevaerts, 1952). According to the Jesuit Van Wing, in 1949, only one girl attended school for about every ten boys (Depaepe and Van Rompaey, 1995: 159), which roughly corresponds with Kita's figures. Additionally, based on official figures (which of course have several shortcomings due, among other reasons, to having been collected by the missions and on occasion having been tampered with in the hope of obtaining possible subsidies, cf. Verbeek, 1987: 8), he puts the number of girls in the total school population of 1934 and 1944 at $9 \%$ and $10 \%$, respectively.

In connection with the difficult start to girls' education, a certain amount of resistance became apparent; however, the responsibility for this was attributed to the endogenous culture rather than the colonial regime itself. According to Kita (2004), this allowed the colonialists to lay the blame with the indigenous population. Perhaps there was some truth to this, and the misogyny and conservatism of the indigenous culture played a role; that said, the ease with which responsibility was shifted onto the Africans once again proved a convenient solution of sorts for the Europeans, who washed their hands of the matter. In any event, polygamy, dowry culture, native customs and psychological conditions (such as the 'laziness' imputed to the indigenous population and the 'unstable nature' of Congolese girls) greatly hampered girls' school attendance, even if most opinion makers subscribed to the Eurocentric assumption that the 'mental powers' of the 'black woman' were considerably more meagre than those of the man, and that she was more attached to traditional customs and 'ancestral ideas' and that 'civilisation' therefore had less sway over her (see also Roobrouck, 2005). However, even for this so-called 'intellectual inferiority' 
an explanation had been found to counteract the possible influence of colonisation, which was almost exclusively a male domain. This was supposedly due, in particular, to the indignity that African women had to suffer daily in their culture because of the men. According to missionaries, men's unmannerly custom of eating separately, insisting at the same time that women serve them, was but one example of this. Furthermore, there was a detrimental influence on the part of village chiefs and maternal uncles who wished to retain the girls for the clan as potential mothers of its future labour force. They were sometimes hidden in the villages when the missionaries were touring the area. As the saying went, 'If you send your sister to school, you might as well eat your fountain pen...' (quoted in Christens, 2003: 350).

Hence the idea that one should not try to make the Congolese girl into a 'white woman', but rather a 'good black', which is to say a baptised and therefore Christian wife and mother, which not only presupposes monogamy, but also the renunciation of all types of superstitions, nudity and the like. To bridge what was sometimes literally a vast distance to the mission, the sisters tried to win the girls over with rewards, both material and spiritual. Those who regularly stayed at the mission in the afternoon could, among other things, count on more 'good points' or they would get new clothes twice a year instead of once. Obviously, this did not solve all of the problems. Missionaries continued to complain about runaway catechists, runaway graduates and pupils who, due to their behaviour, had been expelled from the mission schools (e.g. for teacher training or monastic education). Such cases may have been related to the consequences of modernity, which had also begun to appear in Congo during the interwar period: an increase in rural exodus and nascent urbanisation, increasing unemployment and prostitution, along with other impermissible extramarital relations.

In many respects, the white nuns themselves sought to be an example. Services were provided by them; initially, the sisters only carried out domestic tasks (cooking, sewing, mending) for the priests. According to Dujardin, starting in the 1920s, they gained some independence and diversification in their missionary work. But these trends by no means affected the traditional image of women, since this 'professionalisation' occurred in the fields of education and health care; the nuns were increasingly promoted as good Samaritans, as pious, humble, devoted, caring handmaids, whilst men were cast as militant soldiers of Christ. In the playing out of these idealised examples, an increasing number of native girls were attracted to monastic life. After all, religious life (see Gerard De Boe's (1958) propaganda film, Soeurs congolaises) offered opportunities for individual development and social advancement as well. Prospective novices were impressed with the notion that monastic life encompassed the ideal of emancipation: 'Hail to the devotion in your hearts, with which you have welcomed your emancipation as true women here, to go out to your sisters who are enslaved, bringing them to the freedom which is in Christ' (Christens, 2003: 350). The number of Congolese nuns saw a spectacular rise, from 22 in 1935 to 709 in 1958 (Kita, 2004: 395).

At the height of missionary efforts, which lasted until the 1950s, Catholic educational activity also included non-formal youth and adult education in addition to traditional education and the accompanying extracurricular work. At the centre of it all was the battle against the supposed immorality of modern society. In addition to both standard and extracurricular activities, this idea was mainly encountered in the youth organisations and in the non-formal education specifically for adults. The moral future of Congo, according to the missionaries, was still tied to the success of the Western-oriented family model: 'foyer heureux, foyer uni, foyer chrétien', as the saying went (motto of the Mouvement familial, 
see Depaepe and Van Rompaey, 1995; Ghijssels, 1995). Thus an attempt was made to reach the adult women not only through housekeeping courses, schools and classes on domestic and/or family education, but also through medical advice (pre- and postnatal consultations) and various social services, especially the so-called ouvroirs and foyers sociaux (the first ones appearing in Léopoldville in 1933), where women, usually under the guidance of white women, were familiarised with their role as homemakers and wives. The names given to these services left little to be desired with regard to the image of the ideal woman: 'Rosette', 'La plus belle toilette', 'la fille gentille', 'violette ménagère', and so forth.

As a result, education for women in Congo gradually focussed more on the elite, to whom a key and exemplary role was reserved within the scope of 'emancipation', especially after the Second World War. Oral witnesses (see Vinck et al., 2006) still remember, for example, the Mouvement pour l'émancipation de la femme africaine - a movement rumoured to be supported by soft-hearted white people. Of course, this 'emancipation' must be understood as an umbrella term that has always been interpreted differently depending on the spirit of the times. In this sense, a determination was made that it was not the school's duty to suppress 'natural maternal instinct' and the intellectual apathy associated with it. However, certain elements of the Bantu culture could be included in girls' education: respect for authority, zest for life, hospitality and, last but not least, a fondness for playing with dolls, which were carried everywhere and 'mothered'. Work with the youth and Catholic activities as well - indubitably intended primarily for the men, but in their wake also siphoning off towards the women - could also benefit in part from such an appropriation. But this did not detract from the fact that the youth movements, like those of the Protestants, were meant as an alternative to 'decadent' rites of initiation, 'erotic' dances, and lazing about, which was still seen as the work of the devil. The fact that all of this was associated with puberty and sexuality should not, of course, come as a surprise. On the contrary, according to Bambi Ceuppens (2004: LVI, 315, 325), the idea of a frenzied 'black sexuality' - a 'myth' that attracted various adventurers to Africa - sprang precisely from the rich colonial imagination. For that matter, it was usually the white colonial man who benefited from the sexual hospitality of so-called 'comfort women'. The benefits for African women in comparison, however, were far more meagre, as recent research shows (see Heynssens, 2017).

The 'bifurcation' between the elite and the masses was a structural factor in the educational reform of 1948 (which would be reaffirmed in 1959). The new programme, which was de facto required to correspond with the Ten-Year Plan for economic development (19491959), provided, after the first level of primary education (two years of study, preceded by two years of 'pré-primaire' studies), for two separate educational tracks, one for the masses and one for the elite. The one for the masses generally began, for girls, in the 'standard' second level (which took two or three years of study, depending on the course chosen). There was one exception: the 'école ménagère péri-primaire', which linked directly to the first level of primary education. After the second level, girls entered one of various special schools: the 'cours d'apprentissage pédagogique' (a course of instruction that took two years of study) after two years, and after three years, the 'école ménagère post-primaire' (which took three years of study), a training course to be an 'aide-accoucheuse' (two years of study) or, after a preparatory year, a 'classe de liaison' in the teacher training college (three or four years of study). This last training course (to become a teacher) actually belonged to the elite track, where one normally ended up only after the 'selected' second level (another four years of study). Apart from the regular teacher training college, there was also training 
for 'auxiliaires', which only took two years of study. Furthermore, the elite track offered technical school (two years of study), the 'école moyenne ménagère' (three to four years of study) and nurse/midwife training (three years of study) (Mutamba, 1998: 147; Kita, 2004).

It should be mentioned that despite the increased diversification, all in all, girls' education continued to be quite practically oriented. There was still no programme of general secondary education to speak of that would provide access to the university - Lovanium would not be officially established until 1954 (Mantels and Tollebeek, 2007; Roobrouck, 2005). Nevertheless, the secondary domestic science schools wanted to turn out well-mannered women who, in addition to their 'savoir vivre', had a fair smattering of French. This was considered a prerequisite in view of their future as wives of 'évolués'. Even so, there were a number of évolués - of whom Roger Bolamba writes in La Voix du Congolais - who did not want highly educated wives because they thought they would be less obedient and submissive than their less-schooled counterparts (Ghijssels, 1995: 134). The change of mentality towards the education of girls was therefore a long-term affair, although it may be said that after the Second World War, missionaries generally showed more empathy for young people and took traditional authority into consideration less than before. This was probably due to the fact that they worked together with these young people (Verbeek, 1987: 274).

However, that still did not mean that girls' education was making any real headway. Halfway through the 1950s, the number of girls in publicly run primary education only amounted to $17.7 \%$ (1954-1955 school year), a number that would increase to $28.2 \%$ by the end of the decade (1958-1959 school year, see Mutamba, 1998: 169). Data on Catholic schools has also been found that more or less lines up with percentages found in public schools. For the whole of Congo, among schoolchildren, girls comprised $24 \%$ of enrolment in 1956; in absolute terms, there were 225,730 female pupils compared with 712,964 males (Lambrecht, 1958: III). That the percentage of girls attending school in the capital was even higher is hardly surprising. As part of our previous study (Depaepe and Van Rompaey, 1995), we obtained the following data for participation rates in Catholic primary education for Léopoldville in 1952 (pre-school, primary and post-primary): 8887 boys and 5253 girls, which means that female pupils amounted to $37 \%$, nearly double the rural percentage.

Perhaps more important to note is the growth curve. Based on the official figures collected by Kita, we saw the previously attained percentage of girls in all Congolese primary and secondary schools increase from $9 \%$ in 1934 to $10 \%$ in 1944 to $12 \%$ in 1954 . A serious leap in this percentage would only take place following independence, springing to $32 \%$ in 1964 and $38 \%$ in 1974. However, even without addressing the issue of reliability, it goes without saying that the question remains as to what extent these underlying data are comparable. In any case, they show a trend, as does the growth index that Kita (2003) has calculated over the same period on the basis of the absolute number of pupils. However, this enormous increase (for girls attending school in Congo, this index increased from 100 in 1934 to 182 in 1944 and 462 in 1954 to 2891 in 1964 and even to 7938 in 1974) would, in any case, have to be refined to account for the strong demographic growth as a whole. Moreover, according to the data collected by Kita, the number of unschooled women continued to be quite high. In 1984, 92\% of women over 60 would have preferred not to attend school, and in the 5- to 24-year-old age group, this was still $41 \%$ - and this is with Congo not even having obtained the worst score for all African countries. Based on an international comparison of women's illiteracy in Africa done in 1985, Congo (with a 46.8\% illiteracy rate) was still in fifth place, tied with Kenya (Kita, 2003: 392). Returning to the period before independence, even then, the number of women in Congo who had not 
received a school education was quite high. Other figures (Peeters, 2004: XXII) - which include the mandate of Rwanda-Burundi - indicate $92.7 \%$ for 1952 and $86 \%$ for 1956 , which still points to a slight fall in the 1950s. Nevertheless, the group of women who continued their studies after primary school did not exceed $2.3 \%$ in 1954. Meanwhile, the absolute number of monitrices (female teaching assistants) had risen from 91 in 1934 to 3502 in 1958, and the number of midwife's assistants from 34 in the period before 1939 to 268 in the period 1956-1958 (Kita, 2003: 397, 401). The fact that ultimately, in 1951, there were only 12 women holders of a card of civic merit - which was the point of entry to having the status of a true évolué - out of a total of 395 (or only 3\%) speaks volumes.

The multitude of qualitative processes that lie behind these quantitative data are difficult to trace. Still, the experiences of the oral witnesses that we surveyed in another context (Vinck et al., 2006) may help lift a corner of that veil. We find many indications of the limited study opportunities for women, of the difficult path they had to take, of the resistance and severe punishments, often with the 'chicotte' (Vinck et al., 2006: 51, 62, 93, 95-96), which served to suppress the budding of any emancipatory ideas. As Joséphine (born in 1936) remembers in the following anecdote from her school days:

Our nun came along: 'What! You, a black woman, working in an office? Never will there be a day when a black woman works in an office! She'll work in her husband's house! A black woman will never work in an office! Get out! All of you are to be punished! Get out! You, Joséphine, you're the one coming up with all of these stories! You will stay kneeling for an entire week outside the classroom, with your hands in the air! You'll see, you filthy brat!' I did my punishment. And then punishment became less effective. And as I've told you, I was selected to go teach. (Vinck et al., 2006: 62-63)

Julienne, another witness, who completed her studies in 1949-1950, received a week's worth of punishment at her domestic science school because she was dressed too nicely (due to her sister's marriage). Afterwards, a fellow pupil spied on her by order of the sisters. Moreover, she was punished because she had gone to visit a pupil having 'fallen' from grace, having had given birth to a baby. She was also punished for things she had not done at all, such as a visit to a sorcerer. Every day, she had to go to mass, since 'they' thought she should become a home economics teacher...Perhaps she would then be able to marry an évolué. In this regard, however, everyone had an opinion about that, to include Joséphine:

At that time, évolués were men who had done their training well and who had good jobs; they were well-mannered, they were good men, they had studied well. They were almost like the Whites, I'll put it that way. That's why they were called 'évolués'. That meant that you would see what they were like by how they dressed, by how they held themselves. You'd enter their land, their homes, and you wouldn't see much difference between them and the Whites.

This was why not everyone was itching to get married immediately. Joséphine continued:

Everyone had their thoughts about what would happen when we grew up. Some expected to have an évolué for a husband. To marry a good man, stay at home, have children, and live together happily. Others studied and hoped to work. Some had even been chosen to learn how to work as a nurse... Others preferred to become nuns. Everyone had her own notions about what 
she wanted to do... But I only had one thought: to work, like some of my friends did at that time. (Vinck et al., 2006: 95-96)

On the whole, educational reality changed far more slowly than the opinion makers would have liked. Many missionaries continued to swear by a 'hard' approach, true to their principles. This was also the case for the Sisters of Mary of Pittem, who labelled their pupils from Kolwezi as impulsive and capricious (Depaepe and Van Rompaey, 1995: 221). One does not have to make much effort to find similar reproaches in the archives of other religious orders. African aspirations towards self-development were easily written off as 'pride'.

Nevertheless, Belgians in general and the missionaries in particular believed, on the eve of independence, that they could produce positive results in girls' education. A teacher expressed it this way: 'When a sister displayed a picture of anatomy for the first time, girls started to scream out loud! This lasted for a few decades. Black girls now personally use hypodermic needles and are initiated into the world of medication and instruments...' (Ghijssels, 1995: 109).

\section{The effects of post-colonisation}

As is well known, three periods can be distinguished in the political developments of the Democratic Republic of the Congo: the turbulent years of the First Republic (1960-1965), the flourishing of Mobutu's power during the Second Republic (1965-1997) and the acquisition of dictatorial power by the Kabilas in the Third Republic (1997 to present). During this last period, we have conducted very little research on the history of education in general and that of girls' education in particular. For that reason, we also do not address it fully. With regard to the first two periods, we will rely, inter alia, on the thesis of the co-author, who has thoroughly investigated the topic of girls' education in Kwilu Province (Kikumbi, 2018). From 1963 to 1964, this province was the scene of battle of the Mulele rebels, followers of the (first) Congolese Minister of Education (of the Lumumba government). This rebellion advocated a form of Maoist-inspired camp-based education in which all Western influences were to be completely renounced. This led to a revolt against the missions and their schools, in which the girls also had a share (Lembagusala and Depaepe, 2018). The revolution was smothered with the installation of the Mobutu regime (which was responsible for the brutal death of Mulele). Nonetheless, in the 1970s, Mobutu would also launch an authenticity campaign that aimed to put an end to the colonial educational legacy. Nevertheless, it remained highly debatable as to what extent he would be able to succeed in this at the level of everyday reality in the schools. However, before creating space for a number of oral testimonies, we will first broadly outline the educational policy context, naturally taking the ramifications for girls' education into account.

After the transfer of power on 30 June 1960, Congo fell into political chaos. It is evident that against the background of the chaotic political developments in the First Republic, little time was left to work out a proper educational policy (for what follows, see Depaepe, 1998; Bellens, 1997; Busugutsala, 1986). The only point of agreement was that all positions of leadership had to be filled by Congolese. Still, a gradual reform of education began, designated as a 'programme d'urgence pour donner à chacun sa chance'. The development of secondary and higher vocational education was given priority as a result. According to the 
Decree of 17 July 1961, secondary education would consist of a two-year orientation cycle followed by a 'long' four-year (specialisation) cycle that built upon it which, for girls as well, held out the prospect of university studies. This was an attempt not only to provide the frameworks that the new political situation required, but also to pull Congo out of its cultural isolation. The preferential use of educational structures and content with a Western bias for this purpose was not immediately seen as problematic, even if the reforms of 17 July 1961 (for secondary education) and 17 October 1962 (for primary education) were ultimately intended as a 'désoccidentalisation' of colonial education.

The Decree of 17 October 1962 (No 174) established the structure of primary schools. They had to consist of three levels of two years each (which could be organised separately for boys and girls during the first two levels) and were required to put an end to the colonial distinctions of 'sélection' and 'diversification', which essentially reflected the equally colonial distinction between 'un régime congolais' and 'un régime métropolitain'. In 1963, in its place, a national programme was developed with the common primary education of all children as its goal as well as the cultural emancipation of the people. In contrast to the colonial era, French obtained the status of the official teaching language as from the first years of primary education. The new programme dictated that such gates must be opened to the modern Western world. Nevertheless, with an ideological purge in mind, the fields of history and geography became the subject 'indigenisation'. On the other hand, the BEC (Bureau d'Enseignement Catholique, or Office of Catholic Education) advocated for a return to education in the indigenous languages, especially in the first years of primary school, because there were not enough textbooks and resources available to put the proposed innovations into practice.

During the Mobutu regime, the BEC, with the 'abbe'' Martin Ekwa at its head, was a significant opponent campaigning in educational policy (see, e.g., Ekwa, 2004). Initially, however, the position of the young Congolese church towards the organisation of the educational system was rather hesitant, in sharp contrast with the triumphalism of the colonial era. The path to be followed was not terribly clear. There was confusion, not only because of the painful aftermath of independence, but also due to internal reflection deriving from the Second Vatican Council (1962-1965). The Catholic network could in no way keep pace with the others in terms of educational expansion. According to official sources, the primary school population increased between 1960 and 1965 from 1,664,044 to 2,064,604, which meant growth amounted to a considerable $25.6 \%$, during which time, relatively speaking, Catholic education eroded, falling by some $10 \%$. The major victor was the Kimbanguist schools, which saw their relatively small number of pupils grow from 4491 to 83,447 - an increase of no less than $1758.8 \%$ ! Publicly run schools also saw a gain of $103 \%$. Protestant school attendance rose $20.1 \%$ and that of private schools rose $15.7 \%$. All the same, based on the number of pupils, Catholic schools continued to occupy some $65 \%$ of the market in 1965-1966 (Bellens, 1997: 8-9).

For Mobutu, who seized power in 1965, this was the writing on the wall. There was a gradual evolution towards a radical form of statism. In 1967 (Charter of 20 May), a unity party, the MPR ('Mouvement Populaire de la Révolution'), of which every citizen was a member at birth, came into being. According to Article 1 of Act 70-001 of 23 December 1970, which replaced the Constitution of 1967, the MPR became the highest body of the Republic. The party's leaders, popularly (and scornfully) called the 'Mouvement des Profiteurs du Régime', held the key social positions and passed the central directives on to the common people. Those wishing for a job had to perform various services in exchange, 
which gave rise to an invisible corruption, internally described by Mobutu himself as 'le mal zaïrois' and externally referred to as an organised kleptocracy (MacGaffey, 1998). Initially, the Second Republic did reasonably well economically. Mobutu, the 'président fondateur', re-elected in 1970, 1977 and 1984 to seven-year terms, managed to get the country out of the slump of 1965 .

Blinded by these successes, the Congolese leader launched an 'authenticity' campaign in 1971. Cultural independence was to be brought about by a return to African values and traditions, which naturally implied a revaluation of the indigenous languages. To this end, directives were issued in 1974, 1976 and 1981. To that end, on 31 August 1976, the then Minister of Education decided to introduce a bilingual system whereby the 'national' language as the cultural language of the region prevailed as a standard language, and French, as an 'international' language, shifted to second place, which did not prevent it from continuing to be essential for communication and trade inside the country and within the African continent. Of course, the history books were also rewritten to reflect the contemporary situation, and subjects such as civil studies, music, politics and manual labour appeared on the curriculum. At the same time, the official youth movement of the regime, the 'Jeunesse du Mouvement Populaire de la Révolution', acquired a niche in the educational system, and the wearing of a uniform became compulsory.

Mobutu's earnestness in his pursuit of a 'révolution authentique' became apparent from the name change of 27 October 1971, in which the name of the country and its most important river were changed to 'Zaire' - a derivative of the word 'nzadi', which means 'high water' or 'big water' in Kikongo. Furthermore, Christian names were abolished in 1972, for the authenticity campaign was inevitably coupled with a plea for 'laïcité' or secularism, since the Catholic Church symbolised the colonial past more than any other institution. Joseph Désiré Mobutu would henceforth be known as Mobutu Sese Seko Kuku Ngbendu Wa Za Banga, which meant 'the all-powerful warrior who knows no defeat because of his endurance and uncompromising will, moving from triumph to triumph'. As for the Catholic Church, Mobutu demanded that it submit to the authority of the MPR, which of course was not accepted by the church leaders. As such, on 6 August 1971, Mobutu signed Decree Law 71/075 which, by virtue of Article 56, provided for the establishment of the Université Nationale $d u$ Zaïre. This unitary university served as an umbrella structure for higher education, which brought the Catholic Lovanium under the political control of the MPR. Furthermore, in July 1974, it was decided that all crucifixes would be removed from all public buildings, including schools, to be replaced by portraits of the president. Christmas was abolished as a public holiday, and all education, from primary to university, was placed under the direct authority of the state. In accordance with the decisions of the Political Bureau of the MPR of 30 December 1974, the different networks ceased to exist, and religious instruction was replaced by civic instruction. On 17 January 1975, the Executive Council announced that the nationalisation of the educational system had effectively begun, whereby all property of the educational networks became the property of the state, which of course led to resistance from the Catholic Church, which threatened to bring its education to a halt.

On 6 May 1975, the dialogue between church and state was revived, which, after negotiations that were not always easy (as well as negotiations with the other networks), resulted in the creation of a new convention, which came into effect on 26 February 1977 (Busugutsala, 1986, 1987). What did it contain? The principle of national secularised education was retained, but in a spirit of openness towards the spiritual values of the religions, 
the state could entrust the policies of certain schools to the recognised churches. For these churches, this implied authority over their own personnel, the student population and the internal organisation of their educational systems - with the possibility of (re)establishing religious instruction - as well as finances and school furniture (but not over the buildings, which were the property of the state). However, the entire financial system also appeared not to be functional, partly due to the deteriorating political and economic situation since the mid-1970s. In 1978, the country saw a budget deficit of at least $12 \%$ of national income, an average inflation rate of $80 \%$ and a balance-of-payments deficit of US $\$ 1.3$ billion. The vortex of a runaway inflation rate and falling purchasing power brought Zaire to the brink of ruin, and that included with regard to educational policy, a textbook example of 'everything that can go wrong, will go wrong' (Coleman, 1984: 191). As such, in 1984, the government had to dismiss 7000 teachers in one fell swoop (Depaepe, 1998).

The convention of 1977 was replaced on 22 September 1986 by the Framework Act (No 86005 ) on national education. This act provided for the privatisation (and/or liberalisation) of pre-school, primary and secondary education on the one hand, but held onto the idea of nationalisation for higher and university education on the other. This 'liberalisation' policy included, as 'compensation', a drastic reduction in the subsidy payment - the so-called 'sharing' of the costs, of which almost one-third disappeared due to corruption. This evidently had something to do with the precarious financial situation in which the regime found itself. In addition to the international aid organisations, parents now had to pay as much as possible of the costs of education themselves, with the result that afterwards, many children no longer benefited from education at all. Despite various protests and strikes, after 1986, Zaire slipped into an unprecedented spiral of social and economic impoverishment. The most basic of teaching materials, such as chalk and school benches, could scarcely be found. Reportedly, the share of education in the total budget shrank from $60 \%$ in 1965 to $2 \%$ in 1993 . Whereas the amount per capita spent on education was still US\$27.20 in 1982, this figure dropped to US\$2.90 in 1987 and US\$0.90 in 2006 (under Kabila) (Titeca and De Herdt, 2011: 221).

Yet invariably the Mobutu regime continued to produce favourable results. According to official sources, the school population increased from 1,682,195 to 3,881,950 between 1960 and 1975, and in the 1990-1991 school year, 5,704,646 pupils attended primary and secondary schools, which at first glance seemed like spectacular progress (Vanderlinden, 1980: 86; see, also, Abemba, 1985; Magabe, 1994). After all, the annual growth rate averaged $8.1 \%$ between 1965 and 1980 . However, there are clearly some details that need to be accounted for. Firstly, the expansion in education at that time is much less spectacular when offset against the population explosion Zaire experienced after its independence (14 million in 1960 to 35 million in 1990) and secondly, the school population figures say nothing about the astronomical dropout rate among pupils, which already hovered between 80 and $90 \%$ of the primary school population in the 1960s. If we compare the figures for the 1966-1967 school year with those of 1967-1968, they show that the dropout rate between the first and second year was already 34\%, 16\% between the second and third year, 20\% between the third and fourth year, $13 \%$ between the fourth and fifth year, and $12 \%$ between the fifth and sixth year. Things were not much better for secondary education. Only $18 \%$ graduated in the 1970s, of which only one in seven was admitted to the university. However, there were a few bright spots. In the 1970s, the ratio of participation in secondary education compared with primary education had increased to about $40 / 60$, and with regard to Catholic education, the results of the girls' schools were reported to be better than those of the 
Protestant, publicly run and Kimbanguist institutions - even though the Catholic boys' schools were still leading in terms of academic results and quality. Incidentally, the undeniable growth in secondary education after independence still fell to the girls' disadvantage (Bellens, 1997: 69, 75). The World Bank (Département, 2005: 55) estimated that between 1960 and the mid-1980s, the number of boys (by gender, compared to the age group in question) increased by $3 \%$ to $30 \%$; for girls, that growth was limited to a $1 \%$ increase to $23 \%$. There also seemed to be some progress at the level of girls' higher education. The Catholic network, which still included Lovanium as well as the pre-university division in Bukavu but also teacher training colleges and specialised higher vocational education programmes, included 1233 students from 1969 to 1970, of which 227 were girls (and of which 149 were in teacher training in Kinshasa, see Rideout, 1974: 10). As such, the problem of unequal participation between genders remained firmly in place, just as it did, incidentally, in other parts of Africa (see, e.g., Criel, 1982: 14). Overall, it may be said that the 'new' regime was not in a position to counter social reproduction through the schools.

Instead of dropping, the illiteracy rate shot up among the population, which had been fuelled by the privatisation of primary education starting in the late 1980s. Large-scale training programmes, which the government made much of, did not work; nor did distance education, which, given the vastness of the region, was nevertheless vital. World Bank figures (Département, 2005: 49ff.) indicated that the share of school-aged children in question who actually went to school began to shrink drastically starting in the 1985-1986 school year, whereas from the time of independence up until then, it had been nearly $100 \%$ (with the exception of the 1964-1965 school year, punctuated by the Mulele uprisings, when it was only $78 \%$ ). Between 1985 and 1986, the ratio of the number of schoolboys to the total population of boys of primary school age was estimated at $82 \%$ - a figure that later dropped to $72 \%$ in $2001-2002$, with $49 \%$ in the $1999-2000$ school year as the low point. Naturally, the conflicts at the time, which could conceivably be called an African world war, were responsible for this. However, it is important to note that girls suffered more from these events than boys. It is true that the share of girls attending school out of the total population of potential female schoolchildren increased from $39 \%$ in 1961 to $65 \%$ in the mid-1980s, but then fell again to $56 \%$ in $2001-2002$ (also with $49 \%$ as the low point in 1999-2000) (Département, 2005: 55).

Exodus from the rural areas was also an enormous problem, fuelled all the more by the increasing lack of interest in education in those areas (see, e.g., Balegamire, 1996). Driven by the struggle to belong to the 'framework', parents wanted their children to be able to study, so they fled the countryside, where the schools no longer functioned, even though they knew very well that in addition to the diploma, relationships would be needed to penetrate that framework. Where the average population experienced primary education as 'meaningless rote learning, privation, and physical abuse, in a rigidly authoritarian way', the primary focus of secondary education was still on securing the material benefits of the bourgeoisie, who wanted to maintain class distinction by way of corruptly obtained diplomas (MacGaffey, 1982: 244-245). A more than perfect illustration of this was the fact that the orientation cycle was abolished in 1980. As a result, school enhanced its role as a creator of social disparity. It granted power to a small but self-assured political and economic elite who dominated the rest of the social landscape: the 'sous-bourgeoisie' of merchants and professionals who depended on it, the urban and rural working class, the 'parastatals' and the small independent workers and artisans, as well as the masses of illiterate unemployed 
(including a large number of 'graduates'), the result being that the divide between a Westernoriented, luxurious lifestyle and grinding poverty only deepened.

With MacGaffey $(1982,1998)$ and others, we are also able to conclude that Mobutu's authenticity policy was a total failure. Not only did it rarely go beyond the level of propaganda, but he was also often full of bitter irony. The language used, symbols, images and so forth ultimately served as a continuation of colonialism in many ways: 'the content of the authenticity program presented a picture of indigenous society and culture drawn wholly from what the elite had learned at school, an African sociology informed by political needs, that the new class inherited from their predecessors: for example the political model of African society as a single authoritarian hierarchy headed by an absolute chief' (MacGaffey, 1998: 302).

Lembagusala's study (2018) shows how much girls in secondary education were also participants in this cult of personality. Mobutu was worshipped as a new Messiah in the daily civic education lesson (with salutes to the flag, the national anthem and many other battles songs, in which he was called, e.g., 'le plus puissant, le plus fort, le sauveur, le redresseur, le créateur'). Then came the mandatory 'animation politique', in which so-called authentic dances were given an important role. Henchmen of the regime sought out girls to help spread the greatness of the leader throughout the country - which led to a dropout rate of some $20 \%$. Usually, their career was over, once the sexual appetite of these collaborators had been satiated.

In that respect, two testimonials will suffice (quoted in French in Lembagusala, 2018):

I was barely 12 years old when I started my first year of secondary school at the École Technique des Filles. I was one of the best dancers at the school. One day, during a brief visit to the school, I was spotted by a political authority, who gave me an envelope with banknotes inside. It was my first time handling large wads of money, under the admiring gazes of my classmates. Sometime later, I found myself pregnant, and I could no longer continue my studies. I returned to the village to work in the fields. Since then, I've lived in the country, without work, and with no respect from society.

I came from a rural family. I was 15 years old when I was chosen to take part in a general assembly on militancy held in Kinshasa. There, I met a wealthy man in his sixties. I was driven by many different motives, including a spirit of adventure and the desire to see what opportunities he could offer me. Within a week, the man had bought me a beautiful luxury car. I was dazzled by the fleeting wealth. A year later, our relationship ended and I found myself in indescribable poverty.

The same applied mutatis mutandis to the revolutionary ideal that was presented to the girls by Mulele and his faithful. In the camps, they would be physically toughened in the same way as the boys; their character and will would be shaped so that they would become the champions of a new society, according to the Chinese model. As such, they had no need for Western knowledge; African tradition (or, ironically enough, the tradition labelled by the colonials as African) had to suffice. In reality, murdering, pillaging and burning became their lot, sometimes under the influence of drugs and alcohol. Dreams of emancipatory projects are one thing, but in the complex, historical reality(ies) of post-colonial societies, they accomplish something altogether different. Setting aside the request for financial support, in a country that hardly invests in education, the educational past shows that imposing 
emancipation through a dictatorial flick of the wrist is an impossible task, both in the North and in the South. Finally, here again are some testimonials (quoted in French in Lembagusala and Depaepe, 2018) which may help to corroborate this historical insight:

I was at Kikwit Sacré-Cœur; we were camped in the forest behind the Institut Saint-André. One evening, we went to the sisters to ask for food. As we left their home, we attacked them. Two sisters were seriously injured: Anne-Marie Billiet and Marie-Françoise Lowie. I knew them well because I was from the makwela and my father worked at the mission.

I was in my first year of teacher training school when the rebellion began at the Kisandji mission. All of my friends had left; it was impossible for me to reach the village because of the danger involved. I stayed at the dormitory with a few schoolmates. One evening, we heard noises. It was the rebels, who were pillaging the sisters' house. We watched them being brutalised from a distance. When the rebels arrived at our dormitory, it was a horrible scene: they beat us and raped the students one after the other. Those who resisted were killed immediately. One of the nuns became insane because of it... I had to leave the mission and join my family to escape the fate of many young women at the time. But on the way, I was captured by rebels who took me away to the resistance movement.

From my adolescence up until now, my life has always been marked by the indelible memory of the rebellion. It was very painful to live during this period of unrest. There were bloody victims everywhere.

During their electoral campaign, the members of the African Socialist Party (PSA) promised us an easier life after independence. They promised us teachers that they would triple our salaries. Then we voted for them. They all occupied important positions in the government. The years passed, and our situation did not improve. The ones we had elected grew richer, but we and our children were mired in poverty. That's how I decided to follow Mulele in the resistance movement, to fight against this unbearable inequality.

I was committed to one thing: waging war to destabilise those we voted for, and who forgot their promises, leaving us in poverty that was much more severe than before independence.

\section{Declaration of conflicting interests}

The author(s) declared no potential conflicts of interest with respect to the research, authorship and/or publication of this article.

\section{Funding}

The author(s) received no financial support for the research, authorship and/or publication of this article.

\section{References}

Abemba B (1985) Zaire: system of education. In: T Husen and TN Postlethwaite (eds) The International Encyclopedia of Education: Research and Studies. Vol 9: T-Z. Oxford: Pergamon Press, pp. 5635-5639. 
Balegamire BJ (1996) La formation à Bukavu au Zaire: une course entre l'éducation et la catastrophe. International Review of Education 42(6): 563-579.

Bellens S (1997) De ontwikkeling van het onderwijs in Zaïe (1960-1990). Een exploratieve studie. Masters Thesis, Faculty of Psychology and Educational Sciences, KU Leuven.

Busugutsala Gandayi Gabudisa (1986) Politiques éducatives au Congo-Zaïre. De Léopold II à Mobutu. Paris: L'Harmattan.

Busugutsala Gandayi Gabudisa (1987) Situation récente des rapports Eglise-Etat dans la question scolaire au Zaïre: de la convention de 1977 à la loi-cadre de 1986. Studia Canonica 21(1): 141-174.

Ceuppens B (2004) Congo made in Flanders?: koloniale Vlaamse visies op "blank" en "zwart" in Belgisch Congo. Ghent: Academia Press.

Christens R (2003) De annuntiaten van Heverlee in Afrika 1931-2003. Missionering en ontwikkeling met een vrouwelijk gelaat? Trajecta 12(4): 340-374.

Coleman JS (1984) Professional Training and institution building in the third world: two Rockefeller Foundation experiences. Comparative Education Review 28(2): 180-202.

Criel G (1982) Distribution of Primary School Enrollments in Eastern Africa. World Bank Staff Working Papers, 511. Washington DC: East Africa Regional Office/The World Bank.

De Boe G (1958) Soeurs Congolaises. Flm, edited on cd-rom in 2010, under the title: Belgisch Congo Belge filmed by Gérard De Boe, André Cauvin \& Ernest Genval. Brussels: CINEMATEK.

Delathuy AM (1992-1994) Missie en staat in Oud-Kongo (1880-1914). 2 Vols. Berchem: Epo.

Depaepe M (1998) "Rien en va plus..." The Collapse of the Colonial Educational Structures in Zaire (1960-1995). Education and Society 16(1): 37-53.

Depaepe M (2017) Colonial education in the Congo - a question of "uncritical" pedagogy until the bitter end? Encounters in Theory and History of Education 18(1): 2-26.

Depaepe M and Van Rompaey L (1995) In het teken van de bevoogding. De educatieve actie ni BelgischKongo (1908-1960). Leuven/Apeldoorn: Garant.

Département du développement humain (2005) Le système éducatif de la république démocratique du Congo: priorités et altenatives. Document de travail. S.l. Région Afrique: Banque Mondiale.

Dujardin C (2003) Gender: een beloftevolle invalshoek voor de studie van missie en zending. Trajecta 12(4): 275-306.

Ekwa M (2004) L'école trahie. Kinshasa: Cadicec.

Gevaerts F (1952) De zedelijke vorming en selectie in de inlandse lagere school van Belgisch Kongo Masters Thesis, Faculty of Psychology and Educational Sciences, KU Leuven.

Ghijssels I (1995) Meisjesopvoeding in Belgisch-Kongo (1908-1960). Een oriënterend onderzoek op basis van het archief van de zusters van Liefde. Masters Thesis, Faculty of Arts, KU Leuven.

Heynssens S (2017) De kinderen van Save. Een geschiedenis tussen Afrika en België. Kalmthout: Polis.

Kita Masandi P (2003) De meisjesopvoeding in Belgisch Congo. Trajecta 12(4): 375-407.

Kita Masandi P (2004) L'éducation féminine au Congo belge. Paedagogica Historica 40(4): 479-508.

Lambrecht R (1958) Schoolvorderingentest voor rekenen ten grieve van de zesde studiejaren in de Vicariaten Luluaburg en Kabinda (Belgisch-Kongo). Masters Thesis, Educational Sciences, KU Leuven.

Lembagusala Kikumbi A (2018) L'éducation des filles dans les écoles secondaires du diocèse de Kikwit en R.D. Congo (1960-1997). Contribution des congrégations féminines. PhD Thesis, Faculty of Psychology and Educational Sciences, KU Leuven.

Lembagusala Kikumbi A and Depaepe M (2018) Arme de libération ou force d' (auto) destruction? L'Education des filles congolaises au maquis de Mulele. Historical Studies in Education, in press.

MacGaffey W (1982) Education, religion and social structure in Zaire. Anthropology and Education Quarterly 13(3): 238-250.

MacGaffey W (1998) Am i myself? Identities in Zaire, then and now. Transactions of the Royal Historical Society. Sixth Series 8: 291-307. 
Magabe Mwene J Ch (1994) Zaire: system of education. In: T Husen and TN Postlethwaite (eds), The International Encyclopedia of Education: Research and Studies, 2nd edn, Vol 11. Oxford: Pergamon Press, pp. 6809-6814.

Mantels R and Tollebeek J (2007) Highly educated mission: The University of Leuven, the Missionary Congregations and Congo, 1885-1960. Exchange 36(4): 359-385.

Mutamba Makombo Kitatshima J-M (1998) Du Congo belge au Congo indépendant 1940-1960. Emergence des "évolués" et génèse du nationalism. Kinshasa: Publications de l'Institut de Formation et d'Etudes Politiques.

Peeters L (2004) Het educatieve geheugen van Belgisch Kongo (1908-1960): een vergelijking tussen het katholieke en protestantse meisjesonderwijs in Kongo. Masters Thesis, Faculty of Psychology and Educational Sciences, KU Leuven.

Rideout W M (1974) The Reorganization of Higher Education in Zaire. Overseas Liaison Paper, 5. Washington: American Council on Education.

Roobrouck J (2005) Utopie of universiteit ... of beide? Een geschiedenis van de universiteit van Lovanium (1948-1971). Masters Thesis, Faculty of Arts, KU Leuven.

Titeca K and De Herdt T (2011) Real governance beyond the 'failed state': negotiating education in the Democratic Republic of the Congo. African Affaires 110(439): 213-231.

Vanderlinden J (dir) (1980) Du Congo au Zaire, 1960-1980: essai de bilan. Bruxelles: Centre de recherche et d'information socio-politiques.

Verbeek L (1987) Ombres et clairières. Histoire de l'implantation de l'Eglise catholique dans le diocèse de Sakania, Zaïre. Rome: Libreria Atenao Salesiano.

Vinck H, Briffaerts J, Herman F et al. (2006) Expériences scolaires au Congo Belge. Etude explorative. Annales Aequatoria 27: 5-101.

Yates B (1967) The Missions and Educational Development in Belgian Africa, 1876-1908. PhD Thesis, Columbia University, New York (published in 1975, Ann Arbor (Mich.): University Microfilms).

Marc Depaepe was the deputy chancellor at the KU Leuven, responsible for the campuses at Kortrijk (Kulak), Bruges and Ostend between 2013 and 2017. Since 2005, he has been the co-editor-in-chief of Paedagogica Historica. He was a former president of the International Standing Conference for the History of Education (1991-1994) and member of the Board of directors of the International Academy of Education (2012 to present). He has published and co-published abundantly on the history of education. Some of his selected readings, Between Educationalization and Appropriation, were published in 2012. In 2015, he was awarded an honorary doctorate at the University of Latvia in Riga.

Annette Lembagusala Kikumbi is a doctoral student at the KU Leuven. She belongs to the Sisters of the Annunciation (Heverlee, Belgium) and worked in the Democratic Republic of Congo, among others, in the field of education. Her PhD is on the history of girls' education in the province of the Kwilu (1960-1997). 